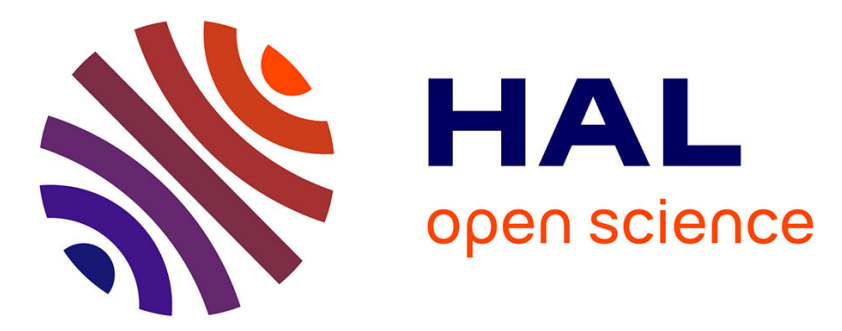

\title{
eradication does not reduce paraprotein levels in monoclonal gammopathy of unknown significance (MGUS): a prospective cohort study
}

Juan-Alfonso Soler, Mercé Güell, Meritxell Bricullé, Antoni Gavarró, Imma Roig, Jordi Sanchez, Javier P. Gisbert, Pilar García, Albert Villoria, Xavier Calvet

\section{To cite this version:}

Juan-Alfonso Soler, Mercé Güell, Meritxell Bricullé, Antoni Gavarró, Imma Roig, et al.. eradication does not reduce paraprotein levels in monoclonal gammopathy of unknown significance (MGUS): a prospective cohort study. Annals of Hematology, 2009, 88 (8), pp.769-773. 10.1007/s00277-008-06844. hal-00535021

\section{HAL Id: hal-00535021 \\ https://hal.science/hal-00535021}

Submitted on 11 Nov 2010

HAL is a multi-disciplinary open access archive for the deposit and dissemination of scientific research documents, whether they are published or not. The documents may come from teaching and research institutions in France or abroad, or from public or private research centers.
L'archive ouverte pluridisciplinaire HAL, est destinée au dépôt et à la diffusion de documents scientifiques de niveau recherche, publiés ou non, émanant des établissements d'enseignement et de recherche français ou étrangers, des laboratoires publics ou privés. 


\title{
H. pylori eradication does not reduce paraprotein levels in monoclonal gammopathy of unknown significance (MGUS): a prospective cohort study
}

\author{
Juan-Alfonso Soler • Mercé Güell • Meritxell Bricullé • \\ Antoni Gavarró • Imma Roig • Jordi Sanchez • \\ Javier P. Gisbert • Pilar García • Albert Villoria • \\ Xavier Calvet
}

Received: 4 July 2008 / Accepted: 18 December 2008 /Published online: 22 January 2009

(C) Springer-Verlag 2009

\begin{abstract}
Monoclonal gammopathy of unknown significance (MGUS) is a chronic haematological alteration that carries a $1 \%$ risk per year of malignant evolution. The origin of this disturbance remains unknown. Previous reports have suggested that a subgroup of patients presenting MGUS might cure after Helicobacter pylori eradication. This study evaluates the effect of $H$. pylori eradication in a cohort of 30 patients with MGUS. A 7-day clarithromycin-based triple treatment was prescribed to patients with MGUS infected with H. pylori. Quantification of the monoclonal component was performed at inclusion and at least 12 months after treatment. The monoclonal component persisted unchanged in all patients who cured the $H$. pylori infection.
\end{abstract}

Keywords Monoclonal gammopathy of unknown significance $\cdot$ Helicobacter pylori $\cdot$ Eradication therapy

\section{J.-A. Soler $(\bowtie) \cdot$ I. Roig}

Servei d'Hematologia, Hospital de Sabadell, Institut Universitari

Parc Taulí, Universitat Autónoma de Barcelona,

Parc Taulí, s/n, 08208 Sabadell,

Barcelona, Spain

e-mail: jsoler@tauli.cat

J. Sanchez $\cdot$ P. García $\cdot$ A. Villoria $\cdot$ X. Calvet

Digestive Diseases Unit, Hospital de Sabadell,

Institut Universitari Parc Taulí, Departament de Medicina,

Universitat Autònoma de Barcelona,

Barcelona, Spain

\section{Bricullé}

Nefrology Department, Hospital de Sabadell,

Institut Universitari Parc Taulí, Departament de Medicina,

Universitat Autònoma de Barcelona,

Barcelona, Spain

\section{Introduction}

Monoclonal gammopathy of unknown significance (MGUS) is a chronic haematological disturbance mainly affecting advanced age individuals. Although it is usually asymptomatic, MGUS carries a $1 \%$ risk per year of malignant disease, mostly multiple myeloma [1]. Helicobacter pylori infection is a well-known cause of gastric and duodenal disease, mainly peptic ulcer and gastric adenocarcinoma. H. pylori has been associated with some haematological disorders and, specifically, with idiopathic thrombocytopenic purpura [2, 3]. Thus, there is growing evidence that near $30 \%$ of patients with this disease improve after H. pylori eradication. H. pylori infection is also the main etiological factor in low-grade gastric mucosa-associated lymphatic tissue (MALT) lymphoma. It has been shown that $H$. pylori infection produces a

M. Güell

Servei de Cirurgia, Hospital de Manresa, Althaia,

Manresa, Barcelona, Spain

A. Gavarró

Laboratori d'Anàlisis Clinics UDIAT-CD Corporació Parc Taulí, Sabadell, Barcelona, Spain

J. Sanchez · J. P. Gisbert • P. García • A. Villoria - X. Calvet CIBEREHD, Instituto de Salud Carlos III,

Madrid, Spain

J. P. Gisbert

Hospital de la Princesa,

Madrid, Spain 
monoclonal expansion of $\mathrm{B}$ cells, finally leading to the appearance of the lymphoma [4]. Furthermore, cure of the infection leads to a long-term remission in most cases of localised disease $[5,6]$. Being also a monoclonal B cell proliferation, it seemed reasonable that chronic antigenic stimulation from the life-long colonisation of gastric lumen by H. pylori could be the cause in some cases of MGUS. In fact, monoclonal gammopathy associated to a Russell bodies gastritis have been described [7, 8], and a few cases of progression from MGUS to gastric MALT lymphoma have been also reported [9].

A recent report has suggested that a proportion of MGUS patients could respond to $H$. pylori eradication. Thus, Malik et al. [10] found a complete response-with disappearance of the monoclonal component from the bloodstream - in 11 of $39(28 \%)$ patients with the disease. These findings, however, have been subsequently challenged. Thus, Rajkumar et al. [11] did not find any evidence of response in a retrospective series of MGUS patients at Mayo Clinic. Later, other authors had shown that eradication of $H$. pylori did not change MGUS evolution in a case report [8] nor in a series of eight patients with associated MGUS and chronic idiopathic neutropenia [12]. Finally, very recently, Veneri et al. [13] treated 16 MGUS patients infected with $H$. pylori. Paraprotein levels remained unchanged in the 15 patients who cured the infection. According to these contradictory data, the evidence on the relationship between MGUS and H. pylori infection remains still controversial. The objective of the study was therefore to evaluate if eradication of $H$. pylori eradication could lead to resolution of monoclonal component in patients with MGUS.

\section{Materials and methods}

Patients with MGUS diagnosed according to standard Kyle criteria [14] at least 6 months before were included. Patients were given information on the nature and risks of $H$. pylori infection and of the controversial evidence on the possibility of response of their disease to H. pylori eradication. Testing for the infection and treatment was proposed. The study was approved by the Ethical Committee of the Hospital de Sabadell. In patients who accepted to participate, written informed consent was obtained.

Determination of $H$. pylori status and treatment

Urea breath test (UBT) was performed according to the Standard European protocol [15]. Patients with a positive UBT received 7-day standard triple therapy including a proton pump inhibitor at standard doses, amoxicillin $1 \mathrm{~g}$ and clarithromycin $500 \mathrm{mg}$ all twice a day. Eradication was evaluated by UBT at least 2 months after eradication. Rescue treatment for patients who failed first-line therapy consisted of 10 days of quadruple therapy with a proton pump inhibitor twice a day, plus tetracycline $500 \mathrm{mg}$, metronidazole $500 \mathrm{mg}$ and bismuth subcitrate $120 \mathrm{mg}$ all three times a day. Again, an UBT was performed at least 2 months after the end of the treatment.

\section{Determination of the monoclonal component}

Cell blood count (CBC), total protein determination and the quantification of monoclonal component were performed at inclusion and at every 6 months.

\section{Statistical analysis}

Data are given as mean \pm SE. Proportions are given along with their $95 \%$ confidence interval. The Wilcoxon test for paired samples was performed to compare the monoclonal component at inclusion and at the end of follow-up. Sample size calculation: According to previous data, we expected a $25 \%$ response rate in patients cured of $H$. pylori infection. To estimate the percentage of responses $\pm 20 \%$ with a $95 \%$ confidence interval, a sample of 20 cured patients was required. Assuming an $80 \%$ cure rate of infection and a $20 \%$ of looses to follow-up, a sample of 28 treated patients was needed.

\section{Results}

Between January 2002 and December 2005, 99 patients were evaluated for inclusion. Fifty-six were males. Mean age was $70.3 \pm 12$ years. Gammopathy was IgA in 17 cases, $\operatorname{IgG}$ in 68 and IgM in 13. The light chain type was kappa in 56 cases and lambda in the remaining 42. One patient presented a combined $\operatorname{IgG}$ and $\operatorname{IgA}$ gammopathy with combined kappa and lambda components. Median time since the diagnosis was 40 months ranging from 6 to 87 months. Forty-four patients did not agree to participate in the study. Of the remaining, nine were $H$. pylori-negative (group 1). Sixteen positive patients did not accept eradication treatment. Finally, 30 received eradication therapy with a proton pump inhibitor at standard doses, amoxicillin $1 \mathrm{~g}$ and clarithromycin $500 \mathrm{mg}$ all twice a day for a week, 11 being cured $(37 \%)$. Three patients who did not cure the infection after first-line treatment accepted a second treatment, and two of them were cured. Thus, after two treatments, 13 patients (group 2) were cured and 33 (16 no treated and 17 treatment failures) remained infected (group 3). A flow diagram of the study is shown in Fig. 1. Characteristics of the patients included in each group are depicted in Table 1. 


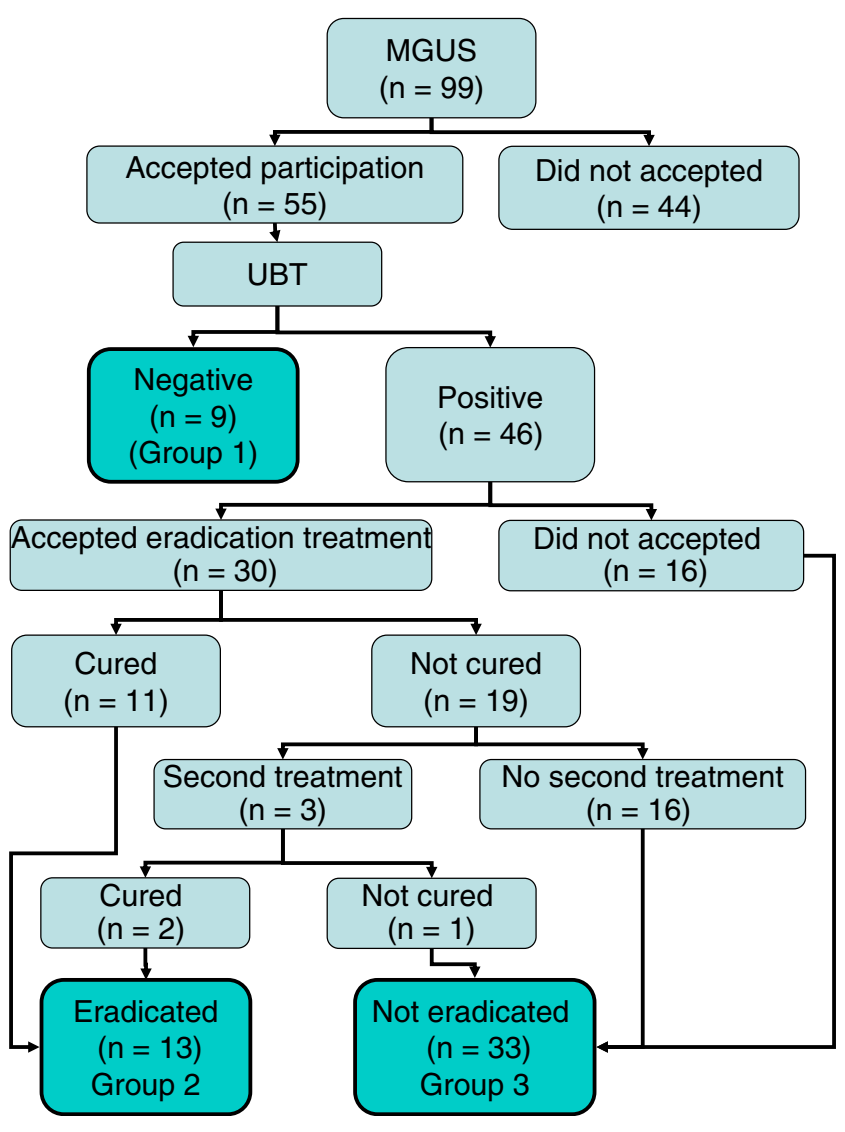

Fig. 1 Flow chart of the patients included in the study

Median follow-up was 19.6 months. None of the patients progressed to multiple myeloma during follow-up. Also, $\mathrm{CBC}$ and total protein neither show significant changes in the whole group nor in the different subgroups in the study. Neither monoclonal gradient nor light chain concentrations decreased in any of the determinations performed after $H$. pylori eradication. On the contrary, mean monoclonal

Table 1 Characteristics of patients

\begin{tabular}{|c|c|c|c|}
\hline & $\begin{array}{l}\text { H. pylori- } \\
\text { negative }(n=9)\end{array}$ & $\begin{array}{l}\text { Eradicated } \\
(n=13)\end{array}$ & $\begin{array}{l}\text { H. pylori } \\
\text { infection } \\
(n=33)\end{array}$ \\
\hline Male & 3 & 9 & 20 \\
\hline Age (mean \pm SD) & $69.3 \pm 2$ & $64.2 \pm 4$ & $69.2 \pm 4$ \\
\hline $\mathrm{IgA} / \operatorname{IgG} / \operatorname{IgM}$ & $3: 5: 1$ & $2: 10: 1$ & $3: 27: 4^{\mathrm{a}}$ \\
\hline Light chain $(\kappa / \lambda)$ & $3: 6$ & $6: 7$ & $20: 14^{\mathrm{a}}$ \\
\hline $\begin{array}{l}\text { Time since the } \\
\text { diagnosis (months) }\end{array}$ & $38.5 \pm 10$ & $40 \pm 7$ & $32.5 \pm 5$ \\
\hline Follow-up (months) & $21.6 \pm 2$ & $26.7 \pm 2$ & $23.7 \pm 1$ \\
\hline $\begin{array}{l}\text { Monoclonal component } \\
(\mathrm{g} / \mathrm{l})\end{array}$ & $15.7 \pm 1$ & $15.6 \pm 9$ & $15.9 \pm 1$ \\
\hline
\end{tabular}

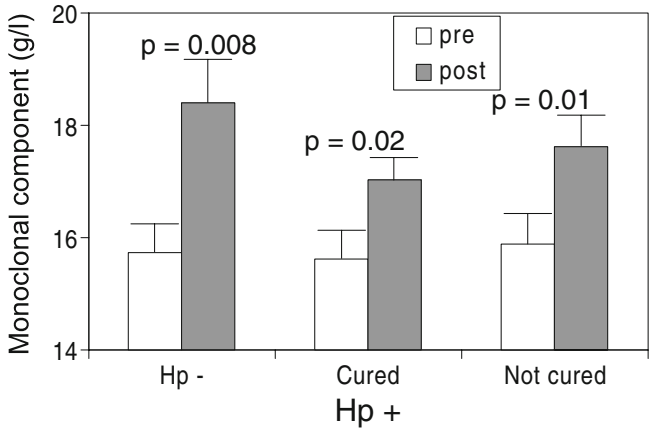

Fig. 2 Monoclonal component values before inclusion and at the end of follow-up in the different groups of patients. $\mathrm{Hp}-\mathrm{H}$. pylori negative (group 1), Hp+ infected by H. pylori. Cured (Group 2) and not cured (group 3)

component of the whole group significantly increased from $15.8 \pm 5.3$ at the beginning to $18.2 \pm 5.3 \mathrm{~g} / 1(p<0.001)$ at the end of follow-up. Changes in the monoclonal component were: $2.7 \pm 0.4,1.4 \pm 0.3$ and $1.9 \pm 0.6$ in groups 1 to 3 , respectively (Fig. 2). In addition, the monoclonal component persisted unchanged or increased in $100 \%(95 \% \mathrm{CI}$, $72-100 \%$ ) of the 13 patient who cured the H. pylori infection (Fig. 3).

\section{Discussion}

Contrasting the initial results of Malik et al. [10], the present series strongly suggests that $H$. pylori eradication does not induce MGUS regression. None of the patients in whom eradication treatment was effective normalised the monoclonal component. Nor even an isolated minor decrease was found. By contrast, in patients in whom the infection was eradicated, the monoclonal component slowly increased to the same degree as in patients with persistent infection or in those without $H$. pylori infection. The study findings were very similar to those found by Veneri et al. [13] who did not found a response in any of 15 treated patients in a similar study. Putting these results together, it

Fig. 3 Value of the monoclonal component before eradication and at the end of follow-up in the patients who cured $H$. pylori infection

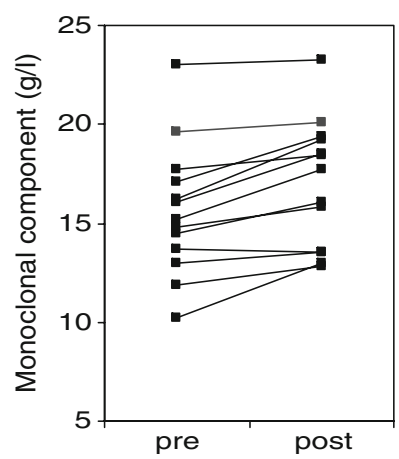


could be reliably affirmed that at least for the vast majority of MGUS patients, treating $H$. pylori did not lead to a reduction of paraprotein. Monoclonal gammopathy has also been described in a small subgroup of patients with MALT lymphoma [16, 17]. However, even in these cases, paraprotein has been associated with a poor response of the lymphoma to $H$. pylori eradication, thus requiring radiation or chemotherapy. In this setting, paraprotein decreases have been observed in those patients responding treatment. It has been suggested therefore that paraprotein production could be a marker for more aggressive disease $[16,17]$.

Two aspects of this study merit to be discussed. First, why could the low cure rate of $H$. pylori infection be explained and second how strongly could be affirmed that H. pylori eradication treatment is ineffective for curing MGUS with 13 patients cured of the infection.

Regarding the first aspect, patient with MGUS are generally of advanced age and often had associated diseases. Antibiotic treatments for respiratory and urinary tract infections are likely to be frequently prescribed. As previous use of macrolides is one of the best predictors for failure of standard triple therapy [18], this fact could account for at least a part of the failures. In fact, although H. pylori resistance to clarithromycin in the elderly was not very frequent some years ago, antibiotic resistances have been steadily increasing in last years, especially in populations receiving frequent antibiotic treatment as children [19]. Additionally, triple therapy seems to be less effective in patients with dyspepsia without ulcer than in those obtained in peptic ulcer patients. It has been hypothesised that a lower degree of inflammation in nonulcer dyspepsia was associated with a decreased permeability to antibiotics or to a lower degree of immune response against the bacteria [20].

The second point is how reliable are the negative results of our study. Despite the small number of patients that cured the infection at the end of the study, zero cured patients out of 13 treated has a strong negative predictive value. It could be calculated that with a degree of confidence of $90 \%$, the maximum possible MGUS cure rate attributable to eradication is lower than $13 \%$. In addition, as stated, a very similar study of Veneri et al. [13] also did not found any response in 15 additional patients after $H$. pylori eradication. Taking into account that no patient showed a normalisation or even a decrease in paraprotein levels in the two studies, the residual probability that eradicating $H$. pylori had a clinically significant effect in MGUS is extremely low.

In conclusion, our study adds strength to the previous evidence against the hypothesis that $H$. pylori eradication might have a beneficial effect on MGUS evolution. In addition, it shows that at least in some selected populations, standard triple therapy achieves very low eradication rates.
Acknowledgements This study has been supported by grants from the Instituto de Salud Carlos III (C03/02 and PI 05/1157 and CIBEREHD) from the Agència de Gestió d'Ajuts Universitaris i de Recerca de la Generalitat de Catalunya (2004ACOM 00041) and from the Societat Catalana de Digestologia.

\section{References}

1. Blade J (2006) Clinical practice. Monoclonal gammopathy of undetermined significance. N Engl J Med 355:2765-2770, doi:10.1056/NEJMcp052790

2. Malfertheiner P, Megraud F, O’Morain C, Bazzoli F, El-Omar E, Graham D, Hunt R, Rokkas T, Vakil N, Kuipers EJ (2007) Current concepts in the management of Helicobacter pylori infection: the Maastricht III Consensus Report. Gut 56:772-781, doi:10.1136/ gut.2006.101634

3. Emilia G, Luppi M, Zucchini P, Morselli M, Potenza L, Forghieri F, Volzone F, Jovic G, Leonardi G, Donelli A, Torelli G (2007) Helicobacter pylori infection and chronic immune thrombocytopenic purpura: long-term results of bacterium eradication and association with bacterium virulence profiles. Blood 110:38333841, doi:10.1182/blood-2006-12-063222

4. Nakamura S, Aoyagi K, Furuse M, Suekane H, Matsumoto T, Yao T, Sakai Y, Fuchigami T, Yamamoto I, Tsuneyoshi M, Fujishima M (1998) B-cell monoclonality precedes the development of gastric MALT lymphoma in Helicobacter pylori-associated chronic gastritis. Am J Pathol 152:1271-1279

5. Chen LT, Lin JT, Tai JJ, Chen GH, Yeh HZ, Yang SS, Wang HP, Kuo SH, Sheu BS, Jan CM, Wang WM, Wang TE, Wu CW, Chen CL, Su IJ, Whang-Peng J, Cheng AL (2005) Long-term results of anti-Helicobacter pylori therapy in early-stage gastric high-grade transformed MALT lymphoma. J Natl Cancer Inst 97:1345-1353

6. Wundisch T, Thiede C, Morgner A, Dempfle A, Gunther A, Liu H, Ye H, Du MQ, Kim TD, Bayerdorffer E, Stolte M, Neubauer A (2005) Long-term follow-up of gastric MALT lymphoma after Helicobacter pylori eradication. J Clin Oncol 23:8018-8024, doi:10.1200/JCO.2005.02.3903

7. Pizzolitto S, Camilot D, DeMaglio G, Falconieri G (2007) Russell body gastritis: expanding the spectrum of Helicobacter pylorirelated diseases? Pathol Res Pract 203:457-460, doi:10.1016/j. prp.2007.01.009

8. Wolkersdorfer GW, Haase M, Morgner A, Baretton G, Miehlke S (2006) Monoclonal gammopathy of undetermined significance and Russell body formation in Helicobacter pylori gastritis. Helicobacter 11:506-510, doi:10.1111/j.1523-5378.2006.00443.x

9. Tursi A, Modeo ME (2002) Monoclonal gammopathy of undetermined significance predisposing to Helicobacter pylorirelated gastric mucosa-associated lymphoid tissue lymphoma. J Clin Gastroenterol 34:147-149, doi:10.1097/00004836200202000-00009

10. Malik AA, Ganti AK, Potti A, Levitt R, Hanley JF (2002) Role of Helicobacter pylori infection in the incidence and clinical course of monoclonal gammopathy of undetermined significance. Am J Gastroenterol 97:1371-1374, doi:10.1111/j.15720241.2002.05668.x

11. Rajkumar SV, Kyle RA, Plevak MF, Murray JA, Therneau TM (2002) Helicobacter pylori infection and monoclonal gammopathy of undetermined significance. $\mathrm{Br} \mathrm{J}$ Haematol 119:706-708, doi:10.1046/j.1365-2141.2002.03912.x

12. Papadaki HA, Pontikoglou C, Stavroulaki E, Minadakis G, Eliopoulos DA, Pyrovolaki K, Skordilis P, Eliopoulos GD (2005) High prevalence of Helicobacter pylori infection and 
monoclonal gammopathy of undetermined significance in patients with chronic idiopathic neutropenia. Ann Hematol 84:317-320, doi:10.1007/s00277-004-0996-y

13. Veneri D, Franchini M, Pizzolo G (2006) Monoclonal gammopathy of undetermined significance and Helicobacter pylori infection. Ann Hematol 85:807-809, doi:10.1007/s00277-0060155-8

14. Kyle RA (1993) "Benign" monoclonal gammopathy-after 20 to 35 years of follow-up. Mayo Clin Proc 68:26-36

15. Dominguez-Munoz JE, Leodolter A, Sauerbruch T, Malfertheiner $P$ (1997) A citric acid solution is an optimal test drink in the 13C-urea breath test for the diagnosis of Helicobacter pylori infection. Gut 40:459-462

16. Wohrer S, Streubel B, Bartsch R, Chott A, Raderer M (2004) Monoclonal immunoglobulin production is a frequent event in patients with mucosa-associated lymphoid tissue lymphoma. Clin Cancer Res 10:7179-7181, doi:10.1158/1078-0432.CCR04-0803
17. Wohrer S, Troch M, Streubel B, Hoffmann M, Mullauer L, Chott A, Raderer M (2007) Pathology and clinical course of MALT lymphoma with plasmacytic differentiation. Ann Oncol 18:2020 2024, doi:10.1093/annonc/mdm375

18. McMahon BJ, Hennessy TW, Bensler JM, Bruden DL, Parkinson AJ, Morris JM, Reasonover AL, Hurlburt DA, Bruce MG, Sacco F, Butler JC (2003) The relationship among previous antimicrobial use, antimicrobial resistance, and treatment outcomes for Helicobacter pylori infections. Ann Intern Med 139:463-469

19. Gerrits MM, van Vliet AH, Kuipers EJ, Kusters JG (2006) Helicobacter pylori and antimicrobial resistance: molecular mechanisms and clinical implications. Lancet Infect Dis 6:699709, doi:10.1016/S1473-3099(06)70627-2

20. Calvet X, Ducons J, Bujanda L, Bory F, Montserrat A, Gisbert JP (2005) Seven versus ten days of rabeprazole triple therapy for Helicobacter pylori eradication: a multicenter randomized trial. Am J Gastroenterol 100:1696-1701, doi:10.1111/j.15720241.2005.50019.x 